\title{
Morphology and infection process of Olivea neotectonae in teak leaves
}

\section{Morfologia e processo de infecção de Olivea neotectonae em folhas de teca}

\author{
Pedro Raymundo Argüelles Osorio' ${ }^{1}$ D, Evelynne Urzêdo Leão ${ }^{1}$ (D), Talita Pereira de Souza Ferreira' ${ }^{1}$, \\ Marcos Vinicius Giongo Alves ${ }^{1}$ (D), Renato de Almeida Sarmento' (D), Gil Rodrigues dos Santos ${ }^{1 *}$ (D)
}

\begin{abstract}
Rust, caused by the biotrophic fungus Olivea neotectonae, stands out as an important disease in teak plantations in Brazil. Considering the current importance of this rust and the need to obtain additional basic information about its causal agent to better disease management, the present study aimed to analyze the morphology of $O$. neotectonae using light microscopy and demonstrate the infection process in teak leaves using scanning electron microscopy techniques (SEM). The morphological characteristics observed using light microscopy were similar to those described in the literature for this species. SEM revealed that the infection structures of the pathogen penetrated the teak leaf through the stomata complex. This study provides the first microscopic evidence of the infection process of Olivea neotectonae in leaves of teak plants.
\end{abstract}

KEYWORDS: Tectona grandis; electron microscopy; morphology.
RESUMO: A ferrugem, causada pelo fungo biotrófico Olivea neotectonae, destaca-se como uma doença importante nas plantaçôes de teca no Brasil. Considerando a importância atual dessa ferrugem e a necessidade de obter informaçôes básicas adicionais sobre seu agente causal para melhor manejo da doença, o presente estudo teve como objetivo analisar a morfologia da O. neotectonae utilizando microscopia de luz e demonstrar o processo de infecção em folhas de teca por meio de técnicas de microscopia eletrônica de varredura (MEV). As características morfológicas observadas em microscopia de luz foram semelhantes às descritas na literatura para essa espécie. A MEV revelou que as estruturas de infecção do patógeno penetraram na folha de teca através do complexo estomático. Este estudo fornece a primeira evidência microscópica do processo de infecçáo de Olivea neotectonae em folhas de plantas de teca.

PALAVRAS-CHAVE: Tectona grandis; microscopia eletrônica; morfologia. 
Teak (Tectona grandis L.) is an exotic forest species that was introduced into Brazil in the late 1960s in the Mato Grosso state, which is where the first commercial plantations were established. Among fungal diseases, rust, caused by Olivea neotectonae T.S. Ramakrishnan and K. Ramakrishnan (= Chaconia tectonae) is the only rust known to occur on teak. Rust has been reported in several teak plantations in Brazil, in addition to other countries of Central America, South America, Asia, Oceania and Africa (PIERI et al. 2011; MESQUITA et al., 2016; KOFFI et al., 2018).

The causal agent of rust teak is a biotrophic fungus and its life cycle is not known yet (MULDER; GIBSON, 1973). First symptoms occur on leaves of plants of all ages, and they begin with small regular and irregular brown to grey necrotic areas that cover the upper leaf surface (PÉREZ et al., 2008). The necrotic areas correspond to numerous subepidermally erumpent uredinia on the lower leaf surfaces. Later the leaves dry up and appear burned, with severe to complete defoliation of young trees in 20-30 days from symptom onset (PÉREZ et al., 2008). The early defoliation reduces the speed of plants growth, causing reduction of the photosynthetic rate and consequently influencing the wood production (MESQUITA et al., 2016). Also, the incidence and severity of rust occur independently of the rainy or dry period.

Considering the current importance of this rust and the need to obtain additional basic information about its causal agent to better disease management, the present study aimed to analyze the morphology of $O$. neotectonae using light microscopy and determine the infection process in teak leaves using scanning electron microscopy (SEM).

Between July 2015 and March 2016, 30 teak leaves with yellow pustules and brown powdery masses on the lower leaf surfaces, characteristics of teak rust, were collected in the Gurupi and Lagoa da Confusão cities, at Tocantins, North region. The leaves were transported to the laboratory in paper bags and stored in a room temperature for one day until the first analysis. The lesions were observed and the urediniospores were scraped under a magnifying glass using a soft-bristled brush, and then the slides were prepared for analysis under a light microscope (40x magnification). A total of 30 urediniospores from three different leaf samples collected at each locality were selected. The following fungal structures: shape, colour, size, germ tube and appressoria were measure. Light microscope visualization and image capture were performed with the aid of the software TSView7.

For the scanning electron microscopy techniques, five adult teak leaves with different degrees of rust severity were collected. The same leaves were cut into small fragments of $0.5 \times 0.5 \mathrm{~cm}$, which were immersed in a solution containing the Karnovsky's fixer $0.1 \mathrm{M}$ (paraformaldehyde $2 \%$, glutaraldehyde $2 \%$, sucrose $1 \%$, calcium chloride $0,005 \mathrm{M}$ in $0.01 \mathrm{M}$ cacodylate sodium buffer, $\mathrm{pH}$ 7.2) and stored for 24 hours in the refrigerator. After this period, the material was transferred to new vials containing cacodylate sodium buffer solution and stored in the refrigerator. Subsequently, the samples were transferred to an osmium tetroxide $\left(\mathrm{OsO}_{4}\right.$ at $\left.1 \%\right)$ + ferrocyanide 1:1 solution for 1 hour; and then dehydrated through passages by increasing concentrations of acetone (30, $50,70,90)$ for 15 minutes once each, and $100 \%$ for 10 minutes three times. Then fragments of leaves were taken to the critical point (model CPD-030-Balzers), where the samples went through baths with $\mathrm{CO}_{2}$ to reach the ideal drying point. Finally, the samples were mounted on stubs with a double tape of carbon and brought to the metallizer (SDC 050 Balzers) where they received a gold bath for three minutes and then were observed in scanning electron microscopy, model JEOL JSM-7001F. The images were captured in the Laboratory of Scanning Electron Microscopy from the Institute of Biological Sciences at the University of Brasilia.

The observed morphological characters of the fungal structures on the leaves collected at both locations are in accordance with those given for $O$. tectonae, the causal agent of teak leaf rust, by MULDER; GIBSON (1973). Initially, small chlorotic spots were observed on the upper leaf surfaces, which subsequently developed to form necrotic lesions (Fig. 1A). On the lower leaf surface, light-yellow-orange-coloured spore masses were observed (Fig. 1B) showing intense sporulation, and red-brown pustules of uredinia (Fig. 1B). Observations performed under the light microscope revealed pedicelled, globose urediniospores that were ovoid to ellipsoid in shape, with colours ranging from yellow to yellow-orange and brown, and size ranging from $16.52-$ $25.11 \times 12.08-23.01 \mu \mathrm{m}$ (Fig. 1C). Dense and marginal paraphyses that were cylindrical and curved were observed. The germ tubes of germinating spores (Fig. 1E) were on average $26.37 \times 2.97 \mu \mathrm{m}$ (Fig. 1D), and appressoria were on average $6.76 \times 3.27 \mu \mathrm{m}$ (Fig. 1D). These pathogen characteristics were also found by other authors, in different areas where the pathogen is present (FERRARI, 2009; PIERI et al., 2011; MESQUITA et al., 2016). Teliospores were not observed, as expected. According to PIERI et al. (2011) teliospores were not yet collected in Brazil. The fungus does not have spermogonians which are known (PIERI et al., 2011). THIRUMALACHAR (1949) reports that teliospores are formed later from uredinia, or in independent sera, subepidermal, formed above the epidermis. The teliospores are clavate, fusi-claviform, sessile, in groups of basal cells with orange content, $38-51 \times 6-9 \mathrm{~mm}$, hyaline walls.

With the aid of SEM, it was possible to observe some of the infection characteristics, as well as the various pathogen structures, such as urediniospores on the leaf surface (Fig. 2A), the urediniospore ultrastructure (Fig. 2B), pustules of $O$. neotectonae sporulating on the leaf surface (Fig. $2 \mathrm{C}$ ), and the curved and hyaline paraphyses in the urediniospores (Fig. 2D). The pathogen penetration method was also observed in the leaf (Figs. 2E and 2G). The figure $2 \mathrm{E}$ 
showed the urediniospores on the leaf surface germinated, germ tube formed and urediniospore withered (Fig. 2E). Appressoria developed at the tips of the germ tubes (Fig. $2 F)$ and penetrated the leaf surface via the stomata complex (Fig. 2G). The stomata were unaffected by the fungus. The passage of the fungus through a stoma appeared to be a purely physical process. It can be verified that the direct penetration by leaf stomata was the main route used by $O$. neotectonae, a fact not yet documented for this patossystem. In the most of Puccinia species, and others rust agents causal, the penetration occurs via stomata (SILVA et al. 2017), as observed in this study. This study provides the first microscopic evidence of the infection process of Olivea neotectonae in leaves of teak plants. As observed, SEM is an important tool for the study of morphological and taxonomic characters of different species of phytopathogenic fungi, as well as making possible the visualization of the structural modifications that occur in the pathogen, due to the different events that can be found during plant-pathogen interaction (MAYDE-MIO et al., 2006). Besides, being a key tool in the classification of fungi of the order Uredinales.

In the interaction of rust fungus with plants, SEM has shown to be extremely useful. SEM analysis performed in rust species, as Puccinia melanocephala on sugarcane, showed the germination, germ tube and appressorium formation on the surface of the leaves (GARCIA et al. 2007), similar to that observed in this study. These authors noted that urediniospores that formed the appressoria began to wilt. This indicates that
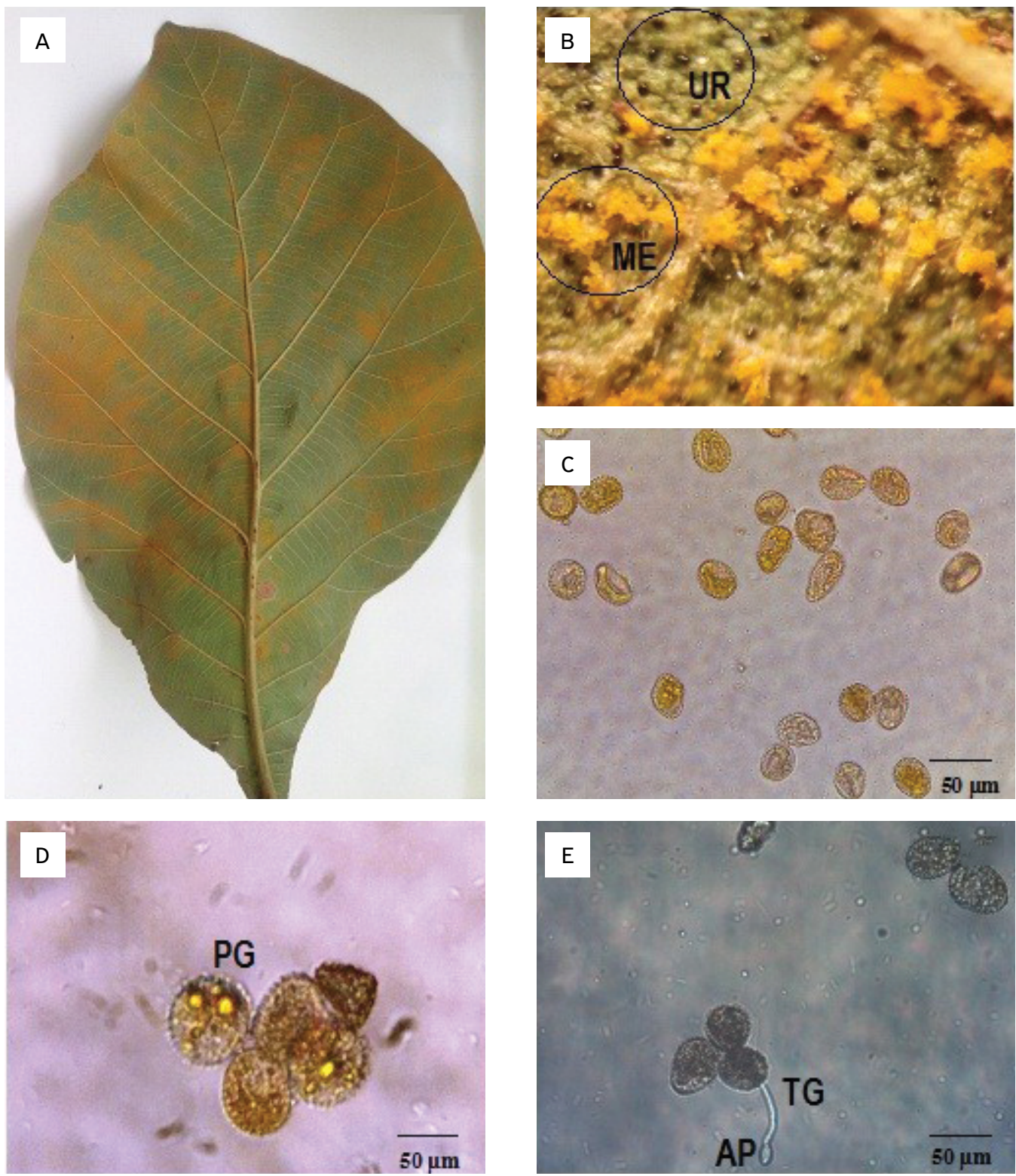

Figure 1. Teak leaf showing symptoms of rust (Olivea neotectonae). (A) Symptoms on the leaves; (B) pustules with intense sporulation, (MEarrow) spore mass in the leaf epidermis, (UR-arrow) uredinia; (C) urediniospores; (D) urediniospores with germinal pores, (PG-arrow) detail of the germinal pores; (E) germination of urediniospores, (TG-arrow) germ tube details, (AP-arrow) appressorium details. 
the cell contents were transferred to the germ tube. The same was observed by MAGNANI et al. (2007), in urediniospores of Phakopsora pachyrhizi.

As a conclusion, this study provides the first microscopic evidence of the infection process of Olivea neotectonae in leaves of teak plants, and it suggests that this infection process might play an important role in the disease development.

\section{ACKNOWLEDGEMENTS}

To The National Council of Science and Technology (CONACYT) of México for providing financial support. The authors thank Dr. Sônia Nair Báo for giving us permission to use the facilities of the Electron Microscopy Laboratory at the Cell Biology Department of Universidade de Brasília.
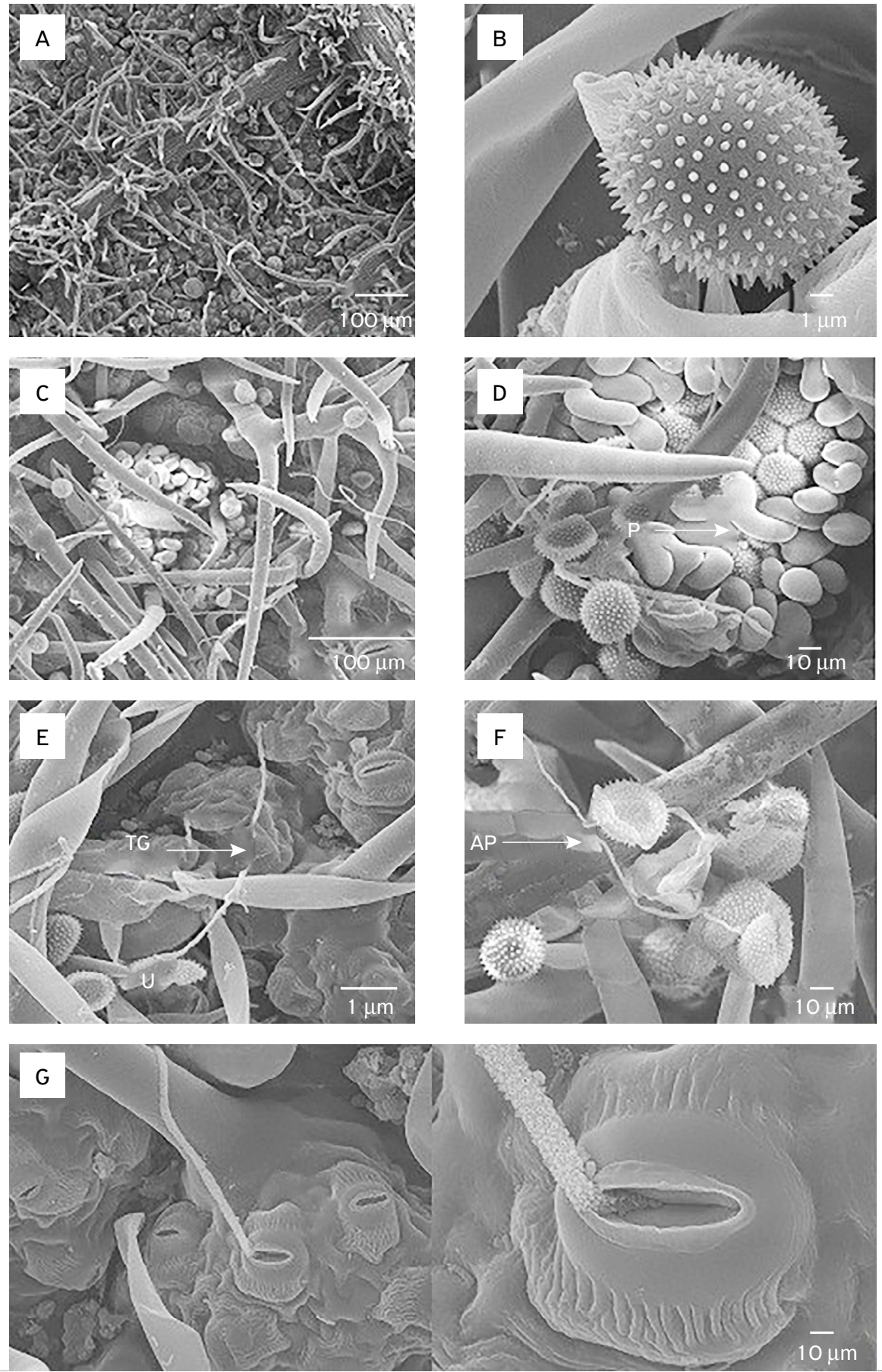

Figure 2. Scanning electromicrographs of teak leaves infected with Olivea neotectonae. (A) Urediniospores on the leaf surface lying between the leaf trichomes; (B) urediniospores; (C) pustules sporulating on the leaf surface; (D) curved and hyaline paraphyses (P- arrow); (E) germinative tube and urediniospore withered (TG-arrow, U-urediniospore); (F) urediniospores with an appressorium (AP-arrow); (G) 0 . neotectonae penetration through the stomata complex. 


\section{REFERENCES}

FERRARI, J.T. Ocorrência de ferrugem (Olivea tectonae) em plantas de teca no Brasil. In: REUNIÃO ANUAL DO INSTITUTO BIOLÓGICO, 22., São Paulo. O Biológico, v.71, p.165, 2009.

GARCIA, E.O.; CASAGRANDE, M.V.; RAGO, A.M.; MASSOLA JUNIOR, N.S. Preservação de urediniósporos de Puccinia melanocephala, agente causal de ferrugem em cana-de-açúcar. Summa Phytopathologica, v.33, n.2, p.152-156, 2007. http:// dx.doi.org/10.1590/SO100-54052007000200009

KOFFI, N.B.C.; N'DOUBA, A.P.; KOUASSI, C.K.; KOFFI, A.M.H.; DIALLO, H.A. First occurrence of teak leaf rust caused by Olivea tectonae in Cote d'Ivoire and Africa. New Disease Reports, v.37, p.22. 2018 . http://dx.doi.org/10.519 7/j.2044-0588.2018.037.022

MAGNANI, E.B.Z.; ALVES, E.; ARAÚJO, D.V. Eventos dos processos de pré-penetração, penetração e colonização de Phakopsora pachyrhizi em folíolos de soja. Fitopatologia Brasileira, v.32, n.2, p.156-160, 2007.

MAY-DE-MIO, L.L.; NOVAES, Q.; ALVES, E. Metodologias de preparação de amostras de ferrugem para estudos morfológicos de urediniósporos por meio de microscopia eletrônica de varredura. Summa Phytopathologica, v.32, n.3, p.267-273, 2006. http:// dx.doi.org/10.1590/S0100-54052006000300009
MESQUITA, J.B.; SANTOS, İ.T.B.F.; RIBEIRO, G.T.; SANTOS, M.J.C. Ocorrência de ferrugem (Olivea neotectonae) em plantas de teca no estado de Sergipe. Summa Phytopathologica, v.42, n.3, p.278279, 2016. http://dx.doi.org/10.1590/0100-5405/2121

MULDER, J.L.; GIBSON, I.A.S. Olivea tectonae. CMI descriptions of pathogenic Fungi and Bacteria, Kew, UK: Commonwealth Mycological Institute, 1973. n.365.

PÉREZ, M.; LÓPEZ, M.O.; MARTÍ, O. Olivea tectonae, leaf rust of teak, occurs in Cuba. Plant Pathology, UK, v.58, n.2, p.397, 2009. https://doi.org/10.1111/j.1365-3059.2008.01993.x

PIERI, C.; PASSADOR, M.M.; FURTADO, E.L.; CARVALHO JUNIOR, A.A. Ferrugem da teca (Olivea neotectonae): novas ocorrências no Brasil e revisão do nome específico. Summa Phytopathologica, Botucatu, v.37, n.4, p.199-201, 2011. http:// dx.doi.org/10.1590/S0100-54052011000400006

SILVA, R.R.; SILVA, A.C.; RODELLA, R.A.; SERRÃO, J.E.; ZANUNCIO, J.C.; FURTADO, E.L. Pre-infection stages of Austropuccinia psidii in the epidermis of eucalyptus hybrid leaves with different resistance levels. Forests, v.8,n.10, p.1-12, 2017.https://doi.org/10.3390/f8100362

THIRUMALACHAR M.J. Telia of the leaf-rust on teak. Current Science, India, v.18, n.5, p.175-177, 1949. 